\title{
In vivo immunostimulatory effect of aqueous acetone extracts of Cienfuegosia digitata Cav. and Sida alba L. (Malvaceae) traditionally used to treat hepatitis B in Burkina Faso.
}

\author{
${ }^{1,6}$ K.Konaté, ${ }^{1}$ A.Hilou, ${ }^{2}$ M.Ouédraogo, ${ }^{3}$ I.C.Dibala, ${ }^{4}$ J. F. Mavoungou, ${ }^{5}$ A.N.Lepengué, \\ ${ }^{6}$ A.Souza, ${ }^{7}$ N.Barro, ${ }^{5}$ B.M'Batchi and ${ }^{1}$ O.G.Nacoulma \\ ${ }^{1}$ Laboratoire de Biochimie et Chimie Appliquées (LABIOCA), UFR/SVT, Université de \\ Ouagadougou, 09 BP 848 Ouagadougou 09, Burkina Faso \\ ${ }^{2}$ Laboratoire de Physiologie Animale, UFR/SVT, Université de Ouagadougou, 09 BP 848 \\ Ouagadougou 09, Burkina Faso. \\ ${ }^{3}$ Laboratoire de Biochimie Alimentaire, Enzymologie, Biotechnologie et Bioinformatique, \\ UFR/SVT, Université de Ouagadougou, 09 BP 848 Ouagadougou 09, Burkina Faso. \\ ${ }^{4}$ Institut de Recherche en Ecologie Tropicale (IRET/CENAREST). BP : 13354 Libreville- \\ Gabon. \\ ${ }^{5}$ Laboratoire de Phytopathologie, UFR Agrobiologie, Faculté des Sciences, Université des \\ Sciences et Techniques de Masuku, BP 943 Franceville-Gabon. \\ ${ }^{6}$ Laboratoire de Physiologie Animale, Electrophysiologie et de Pharmacologie, Faculté des \\ Sciences, Université des Sciences et Techniques de Masuku, Franceville-Gabon \\ ${ }^{7}$ Laboratoire de Biochimie et de Génétique moléculaire microbienne, UFR/SVT, Université de \\ Ouagadougou, 03 BP 7131 Ouagadougou 03.
}

\begin{abstract}
The present study was conducted to evaluate the immunostimulatory effect of aqueous acetone extracts of Cienfuegosia digitata Cav. and Sida alba L. (Malvaceae) on immunosuppressed wistar rats. These herbal plants are traditionally used in Burkina Faso to treat liver diseases. Animals received by gavage $50 ; 100$ and $200 \mathrm{mg} / \mathrm{kg}$ bw of extracts daily for 14 days. Control groups received DMSO $10 \%$ and cyclosporin A. In vivo administration of cyclosporin A for 07 days resulted in an activity on hematological parameters (TWBC and total lymphocytes), serological parameters (CD4 and CD8) and animals body weights when compared with rats which received water $(50,100,200 \mathrm{mg} / \mathrm{kg}$ bw; $p<0.01)$. However, for test groups, it was noticed a decrease of the hematological and, serological parameters and also animals body weights comparatively to the control water group $(\mathrm{p}<0.01)$. We also noticed that extract at a dose of $200 \mathrm{mg} / \mathrm{kg}$ bw was highly effective than 50 and $100 \mathrm{mg} / \mathrm{kg}$ bw compared to the water control group $(p<0.01)$. This study revealed that Cienfuegosia digitata has an immunostimulatory potential compared to Sida alba and these findings could justify the traditional use of the plant in the treatment of hepatitis $B$.
\end{abstract}

Keywords: Malvaceae species, hepatitis B, hematological and serological parameters, immunostimulatory, albinos wistar rats.

\section{INTRODUCTION}

The integrity of human organism in respect of microorganisms is provided by external mechanical and chemical defense barriers and especially by the internal immune system. The strengthening of this immune system with natural products is an important concerns of the African scientific biomedical research (Pichard and Minta, 2002).
Modern medicine now has effective means to alter the course of spontaneous immune responses. Indeed, cell transplants, the injection of extracts of thymus, normal use of mediators and the intensification of an immune response belong to the armamentarium available in boosting immunity. Unfortunately, these treatment strategies for reasons of high cost are often out of reach of people in the Third World (Sylvain, 2001). Indeed, as said Kumar 
and Chandrashekar (2011), nature has provided a complete storehouse of remedies to cure ailment of mankind. In this fact, medicinal plants constitute an effective source of both traditional and modern medicine (Konaté et al., 2011). That explains why plants take up an important place in traditional medicine and scientific research confirmed bioactive properties of lot of plants used in Africa's traditional medicine (Ouédraogo et al., 2007). In many areas of Africa and Asia, the use of plants with immunostimulatory properties is becoming more common. There is a need to perform pharmacological investigations aimed at studying the effectiveness of plants used in traditional medicine and monitor their safety, allowing more efficient use (Alexis, 2003).

New immunostimulants compounds coming from the plants could help the body to fight against multiple infections. These immunogenic substances of plants origin could present three advantages namely restoration of immunity in certain case of immunosuppression, minimizing certain side effects of modern drugs and especially the reduction in the cost of therapy (Fofana, 2004).

These Malvaceae species are widely used in Africa particularly in Burkina Faso as a component of several primitive medicinal remedies against human diseases (Konaté et al., 2010). According to Nacoulma (1996), Cienfuegosia digitata Cav., and Sida alba L. has, in addition to their specific activities, an immune-building ability that gives them special properties, namely the rapid and effective reestablishment of the patient after treatment with these plants. The phytochemical analysis of these two Malvaceae species revealed the presence of saponosides, steroids, polyphenols and alkaloids (Konaté et al., 2010 ; Konaté et al., 2011). Therefore, the present work aims at studying the immunostimulatory effect of aqueous acetone extracts of Cienfuegosia digitata and Sida alba in immunosuppressed wistar rats.

\section{MATERIALS AND METHODS}

Plants material: Cienfuegosia digitata Cav., and Sida alba L. were collected in August 2008 in Gampela, $25 \mathrm{Km}$ east of Ouagadougou, capital city of Burkina Faso. The plants specimens were botanically identified by Prof. Millogo-Rasolodimby (from the plant Biology Department of the University of Ouagadougou). Specimens were deposited at the Herbarium of the Laboratory of Plant Biology and Ecology, University of Ouagadougou.
Animals: Swiss NMRI mice (20-30g) and adult albinos wistar rats $(195-200 \mathrm{~g})$ of both sexes were used. The animals were housed in cage under controlled conditions of 12-h light/12-h dark cycle and $25^{\circ} \mathrm{C}$. They all receive protein-enriched food pellets and water ad libitum.

Acute toxicity study in mice: Healthy male and female Swiss mice $(20-30 \mathrm{~g})$ were randomly divided into 7 groups ( 1 control group and 6 treated assay groups) of 6 animals ( 3 males and 3 females). The animals were deprived of food but not water $15 \mathrm{~h}$ prior to the administration of the test suspension. The control group received intraperitoneally $10 \%$ dimethylsulfoxide (DMSO) solution (in water).

The general behavior of the mice was observed at $120 \mathrm{~min}$ after the treatment. The animals were fed with food pellets and water ad libitum. They were screened for morbidity and mortality once a day for up 14 days. The number of survivors after the 14 days period was noted. The toxicological effect was assessed on the basis of mortality, which was expressed as the median lethal dose $\left(L_{50}\right)$. The $\mathrm{LD}_{50}$ (Lethal Dose 50 was determined according to the method of Miller and Tainter, (1944).

Animals treatment for immunostimulatory potential: The animals were divided into 08 groups of six animals each one. Groups 1 and 2 were used as controls groups.

Group 1: The rats received 10\% DMSO as control by oral way during 21 days.

Group 2: The rats received cyclosporin $A$ as control (25 mg/kg, by oral route) during 07 days (from 1st to 7th day) and then received DMSO $10 \%$ (from 8th to 21st day).

From group 3 to group 8 the animals received various concentrations of plant extracts $(50,100,200 \mathrm{mg} / \mathrm{kg}$ bw) dissolved in $10 \%$. DMSO and were managed during 14 days by oral route (8th to 21 st day of treatment)

Group 3: The rats received extract of Cienfuegosia digitata (50 mg/kg bw.)

Group 4: The rats received extract of Sida alba (50 $\mathrm{mg} / \mathrm{kg} \mathrm{bw}$.)

Group 5: The rats received extract of Cienfuegosia digitata (100 mg/kg bw.).

Group 6: the rats received extract of Sida alba (100 $\mathrm{mg} / \mathrm{kg}$ bw.) 
Agric. Biol. J. N. Am., 2011, 2(12): 1402-1408

Group 7: The rats received extract of Cienfuegosia digitata (200 mg/kg bw.)

Group 8: the rats received extract of Sida alba (200 $\mathrm{mg} / \mathrm{kg}$ bw.).

The animals of groups 2 to 8 initially received cyclosporin A (25mg/kg bw oral route) 1st to 7 th day in order to lower the immune system. The 21st day, the animals were deprived of water and food during 15 hours.

\section{Assessment of immunostimulatory potential:}

At the end of 21-days period, the animals were deprived of food for $15 \mathrm{~h}$ and blood samples were collected by cardiac puncture in two tubes for hematological and serologic parameters analysis. The blood samples (with heparin and without anticoagulant) were centrifuged at $3000 \mathrm{rpm}$ for $5 \mathrm{~min}$ to obtain plasma or serum. Hematological analyses were performed on whole blood, using automatic counter (Mindray Auto hematology Analyser BC$5500)$ to evaluate following parameters: total white blood cells (TWBC), total lymphocytes, using automatic Counter System (SB FACS) serologic parameters (CD8 and CD4) were determined.

Animal weights: The body weights of animals were measured weekly.

Statistical analysis: The data were expressed as Mean \pm Standard deviation (SD) of six determinations $(n=6)$. Results were analysed by one-way ANOVA followed by Dunnett's $t$-test using Prism 4 software. The level of significance was accepted at $p \leq 0.05$.

\section{RESULTS:}

Acute toxicity result in mice: The effect of intraperitoneal treatment of aqueous acetone extracts from Cienfuegosia digitata and Sida alba on mortality and $L D_{50}$ values were determined The value of $L D_{50}$ is $601.8 \mathrm{mg} / \mathrm{kg}$ bw (Cienfuegosia digitata Cav.) and $3200 \mathrm{mg} / \mathrm{kg}$ bw (Sida alba L.). No significant difference in body weight gain of the treated assay groups over the period of observation was found. No statistical difference was observed between the organ weights in the control and the treated groups.

Body weight: The results are summarised in Figure 1. There is no significant difference in body weight gain between control group (cyclosporin A) and the test groups in the first week $(p>0.05)$. However, the last two weeks of treatment showed a decrease in weight of animals from test groups (3 to 8) comparatively to the control group (DMSO 10\%) and $(p<0.01)$.

Haematology and serologic parameters analyses: Figure 2 shows the effects of aqueous acetone extracts of Cienfuegosia digitata Cav. and Sida alba L., on the hematologic and serologic parameters of the rats. It is noticeable that the effect of the extracts concentrations of $50 \mathrm{mg} / \mathrm{kg}, 100 \mathrm{mg} / \mathrm{kg}$ and $200 \mathrm{mg} / \mathrm{kg}$ bw involved a significant decrease of hematologic and serologic parameters $(p<0.01)$ compared to the

group controls (10\%DMSO). But, there is no significant difference $(p>0.01)$ between the group control (cyclosporin A) and the test groups (3 to 8) for the effects of Cienfuegosia digitata Cav. and Sida alba L., on the various parameters.

\section{DISCUSSION}

The diminution of the weights of animals in groups 2 to 8 is due to the toxicity of cyclosporin A. Also, the use of cyclosporin A for a period of one week is due to the bioavailability of cyclosporin $A$, which is poor (20-50\%) (Borel et al., 1976)

These reductions in weight may be due to side effects of this toxic substance for a long time of treatment. Moreover the plant extracts are not very toxic (Raza et al., 2002). According to certain studies, cyclosporin A exhibits mainly renal toxicity $(75 \%$ of patients), the dose should always be adjusted according to creatinine clearance. This product also exhibits neurotoxicity, hepatotoxicity and gastrointestinal toxicity. It is metabolized in the liver by the cytochrome P450-3A and eliminated mainly via the bile (Borel et al., 1976). These results also showed that there is a relationship between the effect of extracts and duration of treatment.

Given the statistical analysis, results show that there is no significant difference in body weight gain between control groups and test groups during the first day of treatment ( $p>0.05)$. However, our results point to a slight increase in weight of animals of test groups $(50 \mathrm{mg} / \mathrm{kg}, \quad p<0.01$ and $200 \mathrm{mg} / \mathrm{kg}$ bw, $\mathrm{p}<0.01)$ compared with the control group 2 (cyclosporin A). These results indicate that the aqueous acetone extract of Cienfuegosia digitata Cav., has a protective power against stress induced by cyclosporin $A$. this is aimmunostimulantory otential. 


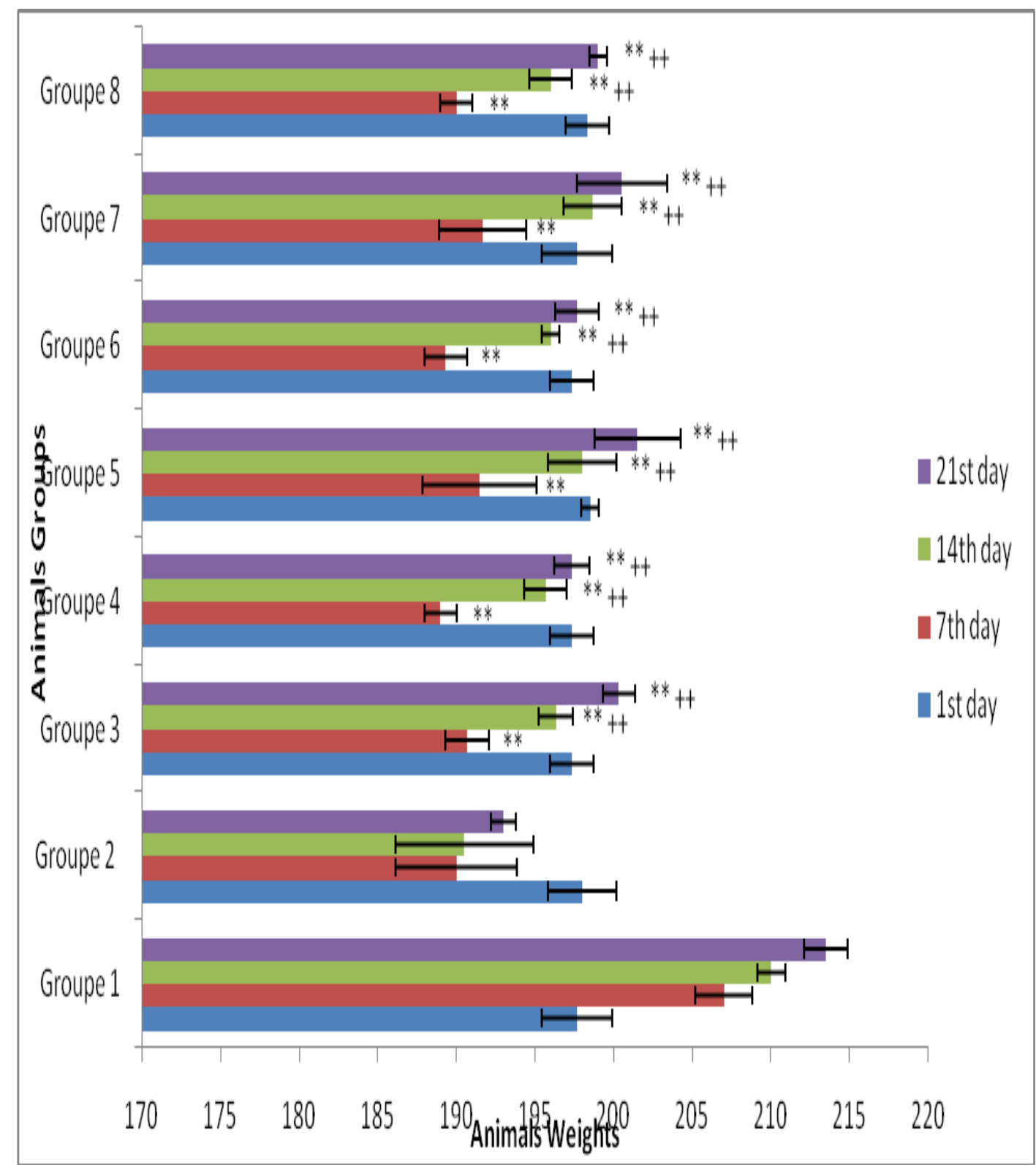

Fig 1: Animal weights (g) with time of treatment

Values are mean \pm S.E.M. $(n=6)$ one-way ANOVA followed by Dunnett's $t$ - test: Compare all vs. control:

${ }^{* *} \mathrm{p}<0.01$ compared with control DMSO $10 \%$

$++p<0.05$ with control cyclosporin A

Group 1: 10\%DMSOcontrol: , the rats received 10\% DMSO during 21 days

Group 2: rats received cyclosporin Afrom 1st to the 7 th day and $10 \%$ DMSO from 8 th to the 21 st day

Group 3: rats received extract of Cienfuegosia digitata (50 mg/kg bw.) dissolved in 10\% DMSO fromthe 8th day tot the $21 \mathrm{st}$ day

Group 4: rats received extract of Sida alba (50 mg/kg bw.) dissolved in 10\% DMSO from the 8th day to the 21 st day

Group 5: rats received extract Cienfuegosia digitata (100 mg/kg bw.) dissolved in 10\% DMSO fromf the 8th day to the $21 \mathrm{st}$ day

Group 6: rats received extract of Sida alba (100 mg/kg bw.) dissolved in $10 \%$ DMSO from the 8th day to the 21 st day

Group 7: rats received extract Cienfuegosia digitata (200 mg/kg bw.) dissolved in 10\% DMSO from the 8th day to the $21 \mathrm{st}$ day

Group 8: rats received extract of Sida alba (200 mg/kg bw.) dissolved in $10 \%$ DMSO from the 8th day to the $21 \mathrm{st}$ 
Agric. Biol. J. N. Am., 2011, 2(12): 1402-1408

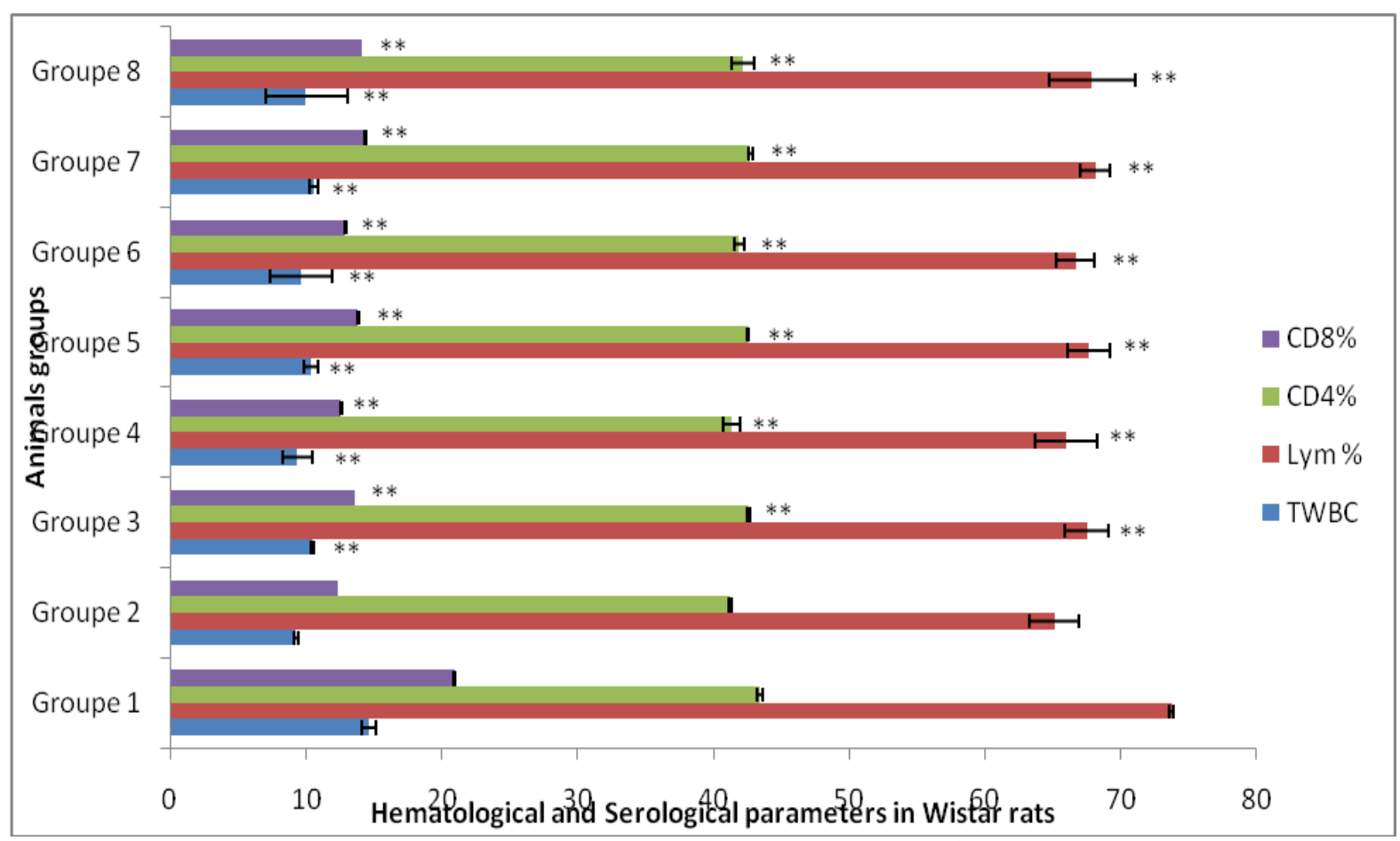

Fig 2: Effects of aqueous acetone extracts of Cienfuegosia digitata Cav. and Sida alba L., on hematological and serological parameters in wistar rats

TWBC $\left(10^{3} / \mu l\right) ;$ Lym $=$ Total Lymphocytes

Values are mean \pm S.E.M. $(n=6)$ one-way ANOVA followed by Dunnett's $t$ - test: Compare all vs. control:

${ }^{* *} p<0.01$ compared with control DMSO $10 \%$

Group 1: $10 \%$ DMSOcontrol: , the rats received 10\% DMSO during 21 days

Group 2: rats received cyclosporin Afrom 1st to the 7th day and $10 \%$ DMSO from 8 th to the 21 st day

Group 3: rats received extract of Cienfuegosia digitata $(50 \mathrm{mg} / \mathrm{kg} \mathrm{bw}$.) dissolved in 10\% DMSO fromthe 8th day tot the $21 \mathrm{st}$ day

Group 4: rats received extract of Sida alba (50 mg/kg bw.) dissolved in $10 \%$ DMSO from the 8th day to the $21 \mathrm{st}$ day

Group 5: rats received extract Cienfuegosia digitata (100 mg/kg bw.) dissolved in 10\% DMSO fromf the 8th day to the $21 \mathrm{st}$ day

Group 6: rats received extract of Sida alba (100 mg/kg bw.) dissolved in 10\% DMSO from the 8th day to the $21 \mathrm{st}$ day

Group 7: rats received extract Cienfuegosia digitata (200 mg/kg bw.) dissolved in 10\% DMSO from the 8th day to the $21 \mathrm{st}$ day

Group 8: rats received extract of Sida alba (200 mg/kg bw.) dissolved in 10\% DMSO from the 8th day to the $21 \mathrm{st}$ day

Konaté et al. (2011) revealed that the weight is a simple index for measuring toxic substances. One might then think that cyclosporin A would have ROSgenerating properties, but also depletes antioxidants, thus creating a state of oxidative stress. This ROSgenerating property is responsible of tissue injury or even cell death which can occur essentially by two mechanisms, necrosis and apoptosis and causing a general unease due to the free radicals (Adly, 2010). A report revealed relationship between antioxidant and free radicals (Ezimah et al. (2008). Certainly, it should not be a balance between free radicals and antioxidants. This balance is the result of disease condition such as weight loss. In doing so, the weight diminution of test groups ( 3 to 8 ) compared to controls ( 1 and 2 ) could be explained just by stress induced by cyclosporin $A$.

On hematological and serological parameters (Figure 2), there is actual evidence that cyclosporin A has an immunosuppressive potential. The increase in hematological and serological parameters of the test group 8, compared to the control group 2 (cyclosporin A control) allows to say that the aqueous acetone extract of Cienfuegosia digitata $(200 \mathrm{mg} / \mathrm{kg}$ bw; $\mathrm{p}<0.01$ ) has a best immunostimulatory effect comparatively to Sida alba. 
These results could be explained by the presence of biologically active antioxidants such as polyphenol compounds contained in the aqueous acetone extract of Cienfuegosia digitata (Konaté et al., 2010) and (Konaté et al., 2011). Indeed, polyphenol compounds are considered as the major contributors to the antioxidant potential of plants (Coulidiati et al., 2011), and antioxidant play an important role in controlling oxidative stress and decreasing disease activity (Nourmohammadi et al., 2010). This relation could be responsible for reducing oxidative stress due to cyclosporin A. These biological antioxidants by inhibiting the action of cyclosporin $A$ have an inhibitory effect on the highly specific $T$ helper response, eliminating the primary cell response to antigen. Indeed, after binding to an intra-cytoplasmic cyclophilin receptor, it blocks the activation pathway and calcineurin-dependent transcription and consequently gene expression of cytokines required for immune response (Kronke et al., 1984). In particular cyclosporin A inhibits the production of IL-2 and IFN- $y$ and expression of receptors to IL-2. Inhibition of $\mathrm{T}$ lymphocyte activation (CD4) led to suppression of cell-mediated reaction but also the humoral response to $T$ dependent. It inhibits the production of interleukin-2 by lymphocytes, which plays an auxiliary role in the development of the immune response. This is well noticeable on the results of cytotoxic T-lymphocyte or CD8, for the inhibition of IL-2 production by T helper cells which in turn inhibits the production of CD8 (Sadlack et al., 1993; Dai et al., 1998).

However, for values of CD4, we do not find significant differences between test groups and cyclosporin A control groups $(p>0.05)$. Significant differences between the control group (10\% DMSO) and test groups could be explained by stress induced by cyclosporin $A$ in the treatment, which stress is indicated by the diminution of CD4.

These regressions of different CD8 result in lower total white blood cells and total lymphocytes. Indeed, CD8 are $T$ cytotoxic immune cells intervening in viral infections. In view of the results of group 8 compared to those of group 2 (cyclosporin A), one could say that our sample has an immunostimulatory effect (200mg/kg bw, $\mathrm{p}<0.01)$.

The active constituents such as flavonoids, flavonols, flavanols and proanthrocyanidins oligomers were found in the aqueous acetone extracts of Cienfuegosia digitata and Sida alba L. (Nacoulma, 1996) and are powerful antioxidants (Fauconneau et al., 1997). The phytochemical analysis carried out on
Cienfuegosia digitata Cav. and Sida alba L., extracts show that they are rich in polyphenolic compounds (Nacoulma, 1996).

Thus, the restoration of the antioxidant defense system in this study may be due in part to the antioxidant activity of polyphenolic compounds (Regi et al., 2002). One could say that polyphenols could be probably responsible for the immunostimulatory potential of Cienfuegosia digitata.

Indeed, surely this low immune power could be explained by the low bioavailability of the extracts administered orally. It is worth noting that the intestinal absorption of plant extracts through the intestinal absorption is often low and weak (Obici et al., 2008).

Finally, the abundance of mucilage as uronic acids, especially in Cienfuegosia digitata Cav. could explain the best immunostimulatory properties of this plant compared to Sida alba L. (Nacoulma, 1996).

Conclusion: The prevalence of infectious diseases including hepatitis B virus, immunosuppressive disease remains very high in Africa, and this mainly because of the low economic level of populations. Also, the upsurge in cases of immunosuppressant is a real public health concern worldwide over the past twenty years. This immunosuppression can be caused by several factors, the most important being: immunosuppressive therapy, excessive intake of drugs such as steroids and immunocompromised patients.

However, the heavy burden of side effects and cost of chemotherapy make that we are heading to herbal medicines. For this, our present results allow to say that Cienfuegosia digitata Cav. has immunostimulatory properties even if they are weak given the oral administration route here used. So Cienfuegosia digitata Cav..., could be exploited as herbal alternative to standard treatment for hepatitis $B$ because it stimulates immune T-cytotoxic cell proliferation that kills viruses.

\section{ACKNOWLEDGEMENTS}

The authors are grateful to the France Embassy in Burkina Faso/EGIDE-France for the mobility scholarship. The authors think also Prof. Millogo Rasolodimby from the plant Biology Department of the University of Ouagadougou for the botanically identified of plants.

\section{REFERENCES}


Alexis, K., 2003. Valuing African pharmacopoeia: Toxicology and pharmacology of Ziziphus mauritiana Lam (Rhamnaceae), a plant known antihypertensive. Ph.D. Thesis, Pharmacy, Faculty of Pharmacy of Abidjan, FT915/B, pp: 137.

Adly, A.A.M. (2010). Oxidative stress and Disease: An updated review. Research Journal of Immunology 3(2): 129-145, 2010. ISSN 1994-7909.

Borel, J.F., C. Feurer, H.U. Gubler and H. Stahlein, 1976. Biological effects of cyclosporin A: A new antilymphocytic agent. Agents Act., 6 : 468-475.

Coulidiati T.H., H. Millogo-Koné, A.Lamien-Méda, M.Yougbaré-Ziébrou, J.Milogo-Rasolodimby and O.G.Nacoulma. (2011). Antioxidant and Antibacterial Activities of Two combretum species from Burkina Faso. Research Journal of Medicinal Plant 5 (1): 4253, 2011. ISSN 1819-3455/DOI:10-3923/ rjmp.2011.42.53.

Dai, Z.H., B.T. Konieczny, F.K. Baddoura and F.G. Lakkis, 1998. Impaired alloantigen-mediated T-cell apoptosis and failure to induce long-term allograft survival in IL-2 deficient mice. J. Immunol., 161: 1659-1663. PMID: 9712028

Ezimah, A.C.U., E.A. Nwankwo, G.R.A. Okogun, J.C. Ihongbe and P.A. Onyeyili et al., 2008. Total Antioxidant Status is Related to the $\mathrm{CD}^{4+}$ cell Count and the clinical state of HIV/AIDS Patients in the Northeast, Nigeria. J.Med. Sci, 8 (1): 49-53. ISSN 1682-4474.

Fauconneau, B., P. Waffo-Teguo, F. Huguet, L. Barrier, A. Decendit and J.M. Merillon, 1997. Comparative study of radical scavenger and antioxidant properties of phenolic compounds from Vitis vinifera cell cultures using in vitro test. Life. Sci., 61: 2103-2110. 10.1016/S0024-3205(97)00883-7

Fofana, S., 2004. Biochemical exploration on the power of three plants immunogenic in Cote d'ivoire: Alstonia Boonei, Mitragyna ciliata, Terminalia catappa (Combretaceae). Ph.D.Thesis, University of Bamako, pp: 123.

Konaté K., Souza A., Lamidi M., Siawaya Djoba J.F., Ella Mendene F.H., J.Millogo-Rasolodimby and O.G.Nacoulma. (2011). Biological and Toxicological Effects of Aqueous Acetone Extract of Cienfuegosia digitata Cav. (Malvaceae) in Mice and Rats. Journal of Pharmacology and Toxicology 6(2):149-157, 2011. ISSN 1816-496X/DOI: 10.3923/jpt.2011.149.157.

Konaté, K., A. Souza, A.Y. Coulibaly, N.T.R. Meda and M. Kiendrebeogo et al., 2010. In vitro Antioxidant, Lipoxygenase and Xanthine Oxidase Inhibitory Activities of Fractions from Cienfuegosia digitata Cav., Sida alba L., and Sida acuta Burn f. (Malvaceae). Pakistan Journal of Biological Sciences 13(22): 1092 1098, 2010. ISSN 1028-8880.
Kronke, M., W.J. Leonard, J.M. Depper, S.K. Arya and F. Wongstaal et al., 1984. Cyclosporin A inhibits T cell growth factor gene expression at the level ofmRNA transcription. Proc. natn Acad. Sci. USA. 81, 5214.

Kumar, T. and K.S. Chandrashekar, (2011). Banhinia Purpurea Linn: A review of its ethnobotany, phytochemical and phamarcological profile. Res. J. Med. Plant, 5(4): 420-431, 2011. ISSN 18193455/DOI: 10. 3923/rimp.2011.420.431.

Miller, L.C. and M.L. Tainter, 1944. Estimation of the ED50 and its error by means of logarithmic probit graph paper. In: Proceedings of the society for Experimental Biology and Medicine, vol. 57, pp. 261-264.

Nacoulma, O.G., 1996. Medicinal plants and their traditional uses in Burkina Faso. Ph.D.Thesis, University of Ouagadougou, pp: 328.

Nourmohammadi, I., S. Athari-Nikazm, M.R. Vafa, A. Bidari and S. Jazayeri et al., 2010. Effects of Antioxidant supplementations on Oxidative stress in Rheumatoid Arthritis Patients. Journal of Biological Sciences 10 (1): 63-66, 2010. ISSN 1727-3048.

Obici, S., F.J. Otobone, V.R. da Siva Sela, K. Ishida and J.C. da Silva et al., 2008. Preliminary toxicity study of dichloromethane extract of Kielmeya coriacea stems in mice and rats. J. Ethnopharmacol., 115: 131-139. 10.1016/j.jep.2007.09.013. PMID: 17997061

Ouédraogo, Y., I.P. Guissou and O.G. Nacoulma, 2007. Biological and Toxicology Study of Aqueous Root Extract from Mitragyna inermis (Willd oktze) Rubiaceae. International Journal of Pharmacology 3(1): 80-85, 2007.ISSN 1811-7775.

Pichard, E. and D. Minta, (2002). Infectious diseases, $225 \mathrm{P}$.

Raza, M., O.A. Al-Shabanah, T.M. El-Hadiyah and A.A. AlMajed, 2002. Effect of prolonged vigabatrin on hematological and biochemical parameters in plasma, liver and kidney of Swiss albino mice. Scientia Pharmaceutica 70, 135-145.

Regi, R.K., M.C. Sabu and R. Kuttan, 2002. Hypoglycaemic effect of methanol extract of Phyllanthus amarus Schum and Thonn on alloxan-induced diabetes mellitus in animals and its relation with antioxidant potential. Indian J. Exp. Biol., 40: 905-909.

Sadlack, B., H. Merz, H. Schorle, A. Schimpl, A.C. Feller and I. Horak, 1993. Ulcerative colitis-like disease in mice with disrupted interleukin-2 gene. Cell, 75: 253261.

Sylvain, B., 2001. Influence of Treatment with OLSU and ASBO (Two Herbal Medicines) on the Electrophoretic Pattern of Serum Proteins in Rabbits. DEA, Faculty of Medical Sciences, Abidjan, pp: 30. 